\title{
Ependymoma with Intraorbital Extracerebral Recurrence: Case Report
}

\section{Ependimoma com recidiva extracerebral intraorbital: relato de caso}

\author{
Lívio Pereira de Macêdo ${ }^{10}$ Benjamim Pessoa Vale ${ }^{2,3}$ Marx Lima de Barros Araújo 2,3,4 \\ João Cícero Lima Vale ${ }^{5}$ Yally Dayanne Oliveira Ferreira ${ }^{6}$ Suelen Maria Silva de Araújo ${ }^{7}$
}

${ }^{1}$ Hospital da Restauração, Recife, PE, Brazil

2 Instituto de Neurociências do Piauí, Teresina, PI, Brazil

${ }^{3}$ Hospital São Marcos, Teresina, PI, Brazil

${ }^{4}$ Hospital Universitário, Universidade Federal do Piauí, PI, Brazil

${ }^{5}$ Faculdade Facid Wyden, Teresina, PI, Brazil

${ }^{6}$ Centro Universitário Maurício de Nassau, Recife, PE, Brazil

${ }^{7}$ Universidade Católica de Pernambuco, Recife, PE, Brazil

\begin{abstract}
Address for correspondence Lívio Pereira de Macêdo, MD, Departament of Neurosurgery, Hospital da Restauração, Recife, PE, Brasil, 50050-200 (e-mail: livio21@gmail.com).
\end{abstract}

Arq Bras Neurocir 2019;38:342-347.

\section{Abstract \\ Keywords \\ - ependymoma \\ - ependymal cell \\ - anaplastic ependymoma \\ - supratentorial glioma}

Resumo
Ependymomas are rare neuroepithelial tumors that originate from a type of glial cell called ependymal cell. In general, they correspond to $\sim 1.2$ to $7.8 \%$ of all intracranial neoplasms, and to $\sim 2$ to $6 \%$ of all gliomas. Although it corresponds only to $\sim 2$ to $3 \%$ of all primary brain tumors, ependymoma is the fourth most common cerebral neoplasm in children, especially in children younger than 3 years of age. ${ }^{1,2}$ In patients younger than 20 years of age, the majority $(90 \%)$ of ependymomas are infratentorial, more precisely from the IV ventricle. In spite of this, in adults, medullary ependymomas are more frequent (60\%). In this context, supratentorial and extraventricular ependymomas, as in the case reported in the present article, are infrequent in both adults and children. ${ }^{1,2}$ Both sexes are equally affected. ${ }^{3}$ Recurrence of intracranial ependymomas occurs in almost $50 \%$ of the cases, and the followup outcome is not favorable. ${ }^{4}$ In another perspective, the recurrence of extracerebral ependymomas is extremely rare, and even more unusual in the intraorbital site, as it occurred in the case in question.

Ependimomas são raros tumores neuroepiteliais originados de um tipo de célula glial chamada célula ependimária. Em geral, correspondem a cerca de 1,2 a7,8\% de todas as neoplasias intracraniais, e a cerca de 2 a $6 \%$ de todos os gliomas. Embora corresponda apenas a cerca de 2 a $3 \%$ de todos os tumores cerebrais primários, o ependimoma é a quarta neoplasia cerebral mais comum em crianças, principalmente nas menores de 3 anos. ${ }^{1,2}$ Em pacientes com menos de 20 anos, a maioria (90\%) dos ependimomas são infratentoriais, mais precisamente oriundos do IV ventrículo. A despeito disso, nos adultos são mais frequentes $(60 \%)$ os ependimomas medulares. Nesse contexto, received

April 19, 2019

accepted

July 1,2019
DOI https://doi.org/

$10.1055 / \mathrm{s}-0039-1695761$. ISSN 0103-5355.
Copyright (e 2019 by Thieme Revinter

Publicações Ltda, Rio de Janeiro, Brazil
License terms

(c) $(1) \$$ 
ependimomas supratentoriais e extraventriculares, como o do caso relatado no

Palavras-chave

- ependimoma

- célula ependimária

- ependimoma anaplástico presente artigo, são infrequentes tanto em adultos quanto em crianças. ${ }^{1,2}$ Ambos os sexos são afetados igualmente. ${ }^{3}$ A recorrência de ependimomas intracraniais ocorre em quase $50 \%$ dos casos, sendo o resultado de seu seguimento não muito favorável. ${ }^{4}$ Em outra perspectiva, a recorrência extracerebral dos ependimomas é extremamente rara, sendo ainda mais incomum o sítio intraorbital do caso em questão.

\section{Introduction}

Ependymomas are rare neuroepithelial tumors that originate from a type of glial cell called ependymal cell. Found in the ventricular system, the choroid plexus, the terminal filament and the central canal of the spinal cord, these ciliated cells have a role in the production and circulation of cerebrospinal fluid (CSF). Such are the most common sites for the development of this type of glioma, and the ventricle is the most frequent location. ${ }^{1-3}$

The etiology of the onset of ependymomas, as well as of other tumors, is still unknown. However, a possible infectious etiology has been reported by Bergsagel et $\mathrm{al}^{4}$ (1992) and Lednicky et $\mathrm{al}^{5}$ (1995), who demonstrated, using the polymerase chain reaction (PCR) technique, the probable involvement of the simian virus 40 (SV40) in the origin of ependymomas. ${ }^{4,5}$ However, further epidemiological studies are needed to clarify this hypothesis. Also regarding the etiology of these tumors, the role of genes is important, since it is remarkable in some studies that the most common chromosomal alteration found in ependymomas is the loss of an allele of chromosome 22, a fact that probably entails the loss of a suppressor gene of the tumor other than the already known neurofibromin 2 (NF-2) and hSNF5/INI1 genes., 3

It is also important to inform that endocrine factors can help in the mechanism of origin of this neoplasia, since the presence of sex hormone receptors in an anaplastic variant of the ependymoma has already been found, and the other types may share this characteristic. ${ }^{7}$ According to the epidemiological observation, it is important in the clinical practice to emphasize that ependymomas occur more in neurofibromatosis patients than in the general population. ${ }^{7}$

According to WHO histological classification in 2007, ependymoma can be divided into four types: (1) subependymal (WHO I grade); (2) myxopapillary ependymoma (WHO I grade); (3) ependymoma (WHO II grade), including cellular leiomyoma, clear cell type, papilla cell type and tanycyte; (4) anaplastic ependymoma (WHO III grade), belonging to a malignant tumor.

Recurrent intracranial ependymomas occur in almost 50\% of the cases; however, extracerebral recurrence is extremely rare. In the present article, a rare case of extracerebral recurrence of an ependymoma is described. ${ }^{8-10}$

\section{Case Report}

G.S.B., 15 years old, female, from the city of Bertolínea, state of Piauí, Brazil, came to the medical service in 2011 presenting persistent headache, painful supraorbital bulge on the right side, with progressively growing and without acuity visual alteration. In the anamnesis, we verified that the patient had undergone a microsurgery for resection of a right frontal anaplastic ependymoma, in another service in 2001, without any degree of differentiation and with a mitotic index of 3 per 10 high-power fields (HPFs), being submitted to adjuvant treatment with radiotherapy located in the right hemisphere at the same time. At the neurological examination, the patient presented palpebral ptosis due to the involvement of the third pair on the right, had no motor deficit, and the deep reflexes were alive. In the imaging tests, we verified that this was a case of recurrence in the parenchyma and at the base of the skull. Then, the patient was submitted to a microsurgery for the resection of the recurrent tumor in the parenchyma and skull base, compromising the right orbit ceiling, and a reconstruction was performed with a pericranial flap. In spite of that, in the magnetic resonance imaging (MRI) control exam after the microsurgery, a residual lesion in the right orbit was observed. The evolution of oncology was then demanded. In the histopathology, we found that it was a neoplasia with a clear-cell pattern, with diffuse expression of the $S-100$ protein and focal perivascular expression of the glial fibrillary acidic protein (GFAP), with anaplastic ependymoma as the main hypothesis (-Fig. 1).

After 5 months of outpatient follow-up, the patient returned to the service presenting with a rapid and progressive increase of the orbital and supraorbital regions to the right, local hyperalgesia, exophthalmos, and a significant decrease in visual acuity (-Fig. 2). In the complementary examination, there was an injury with invasion of the right orbit and of the periorbital musculature (-Figs. 3 and 4 ).

An image-guided tumor resection was performed in the right orbital cavity in a block with the eyelids, as well as orbital exenteration and resection of the lateral wall of the orbit. In the postoperative histopathological analysis, the diagnosis of anaplastic ependymoma, with the periorbital soft tissues and orbital bone tissue compromised by the neoplasia, and with the ocular globe and optic nerve free of neoplasia, the extracerebral recurrence of this type of glial tumor, which is quite rare, was confirmed. -Fig. 5 and 6 show the postoperative control of this procedure. Adjuvant chemotherapy was performed.

\section{Discussion}

Ependymomas were considered an independent entity for the first time by Bailey and Cushing ${ }^{31}$ in their first classification of brain tumors (1926). Over the course of the 


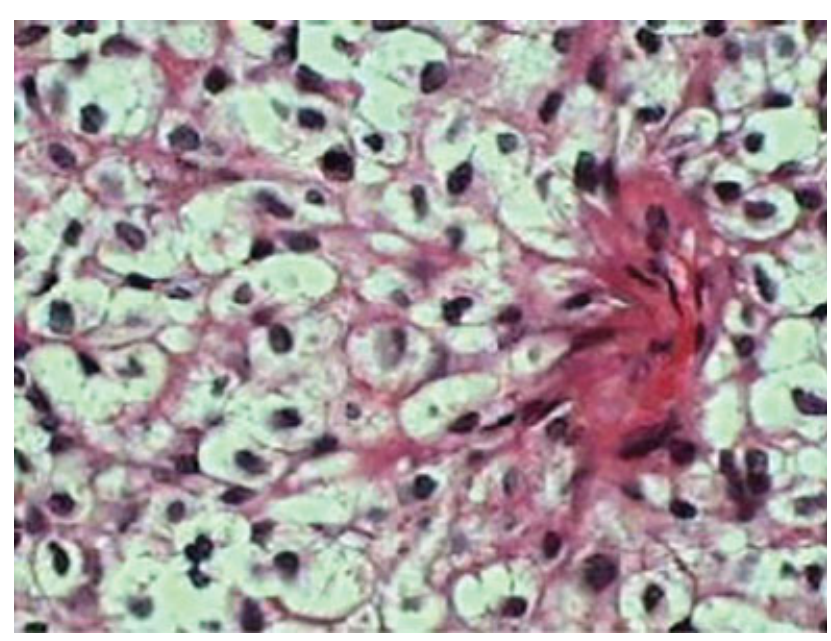

Fig. 1 Hypercellular neoplasm with clear cytoplasmic cells with tendency to perivascular disposition - clear-cell ependymoma.

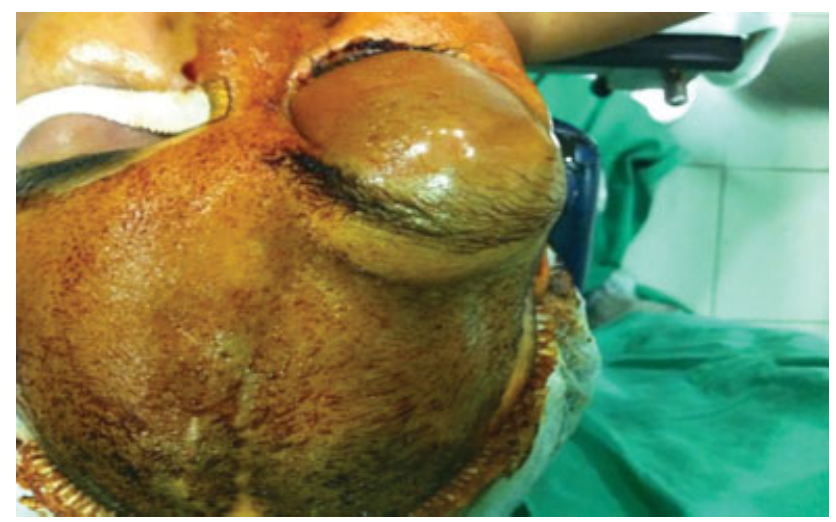

Fig. 2 Preoperative period for tumor resection and orbital exenteration.

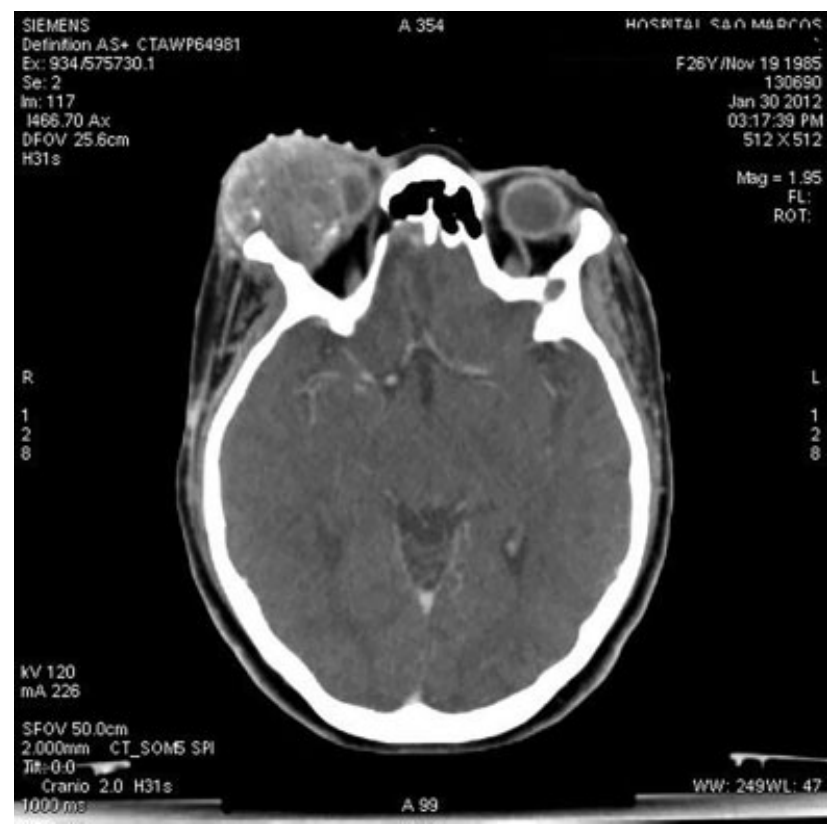

Fig. 3 Tumor mass in the right orbit and invasion of the periorbital musculature.

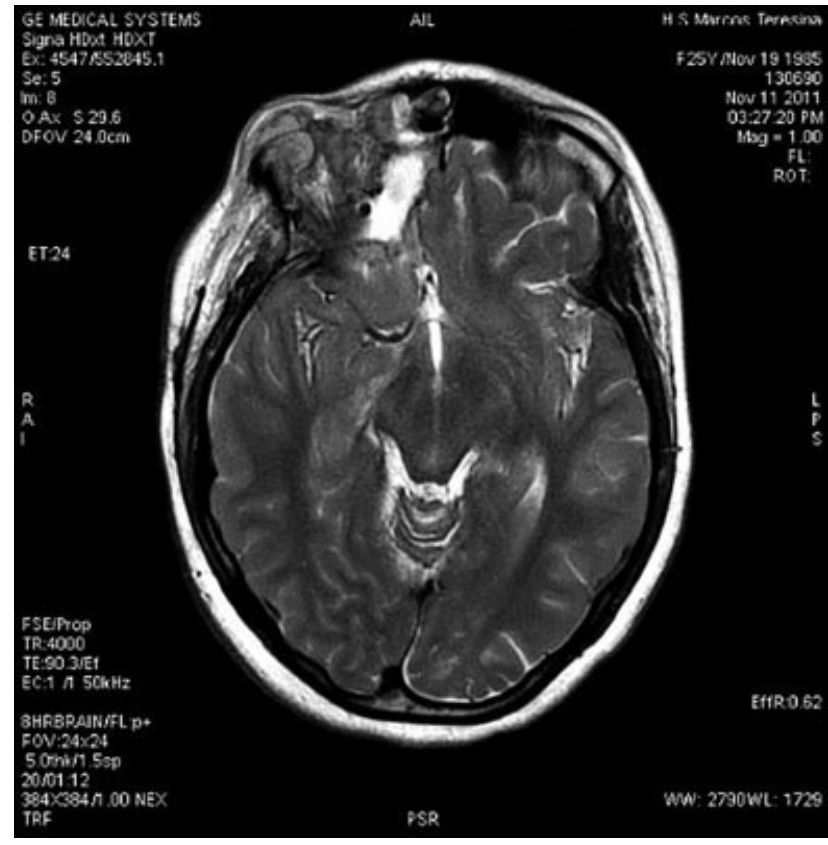

Fig. 4 Tumor mass on the right side of the base of the skull.

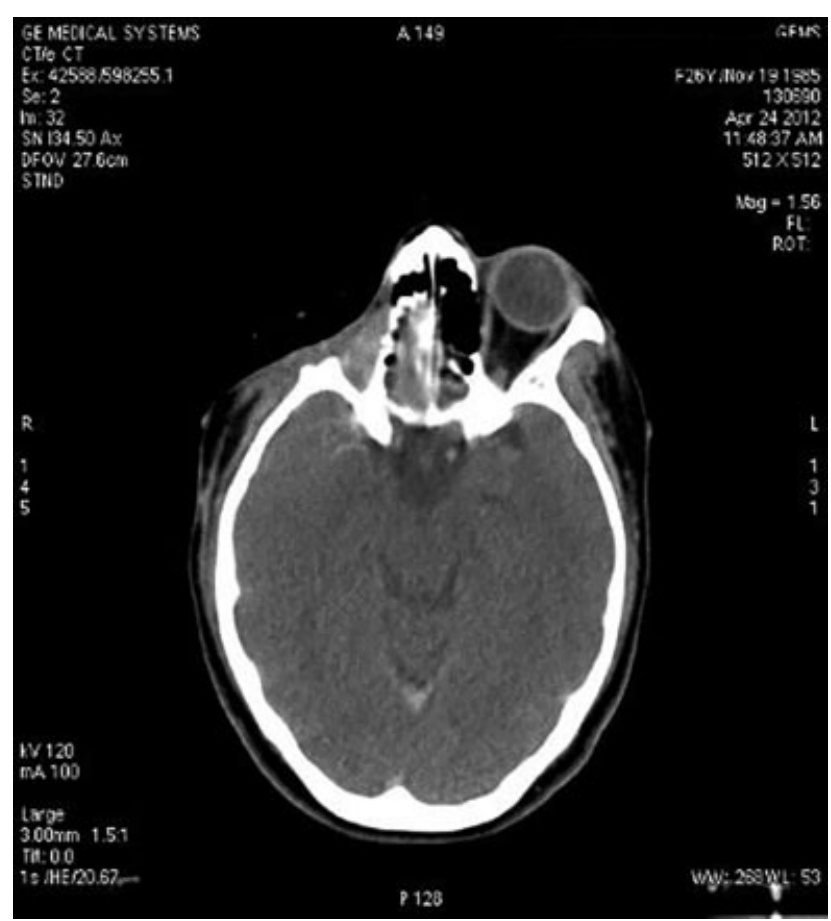

Fig. 5 Postsurgical control image.

years since the first classification, the variants of ependymomas were defined. In 1932, Kernohan ${ }^{32}$ defined the myxopapillary variant, and, in 1945, Scheinker ${ }^{33}$ described the subependymoma. Only in 1978, Friede and Pollack ${ }^{11}$ described the tanycytic variant, and in 1989 Kawano et al $^{34}$ identified clear-cell ependymomas. The 2007 World Health Organization $^{16}$ (WHO) classification considers the subdivision of ependymomas into these 4 histological variants (cell, papillary, tanycytic and clear cells) in addition to the degree of malignancy, including in grade I tumors the 


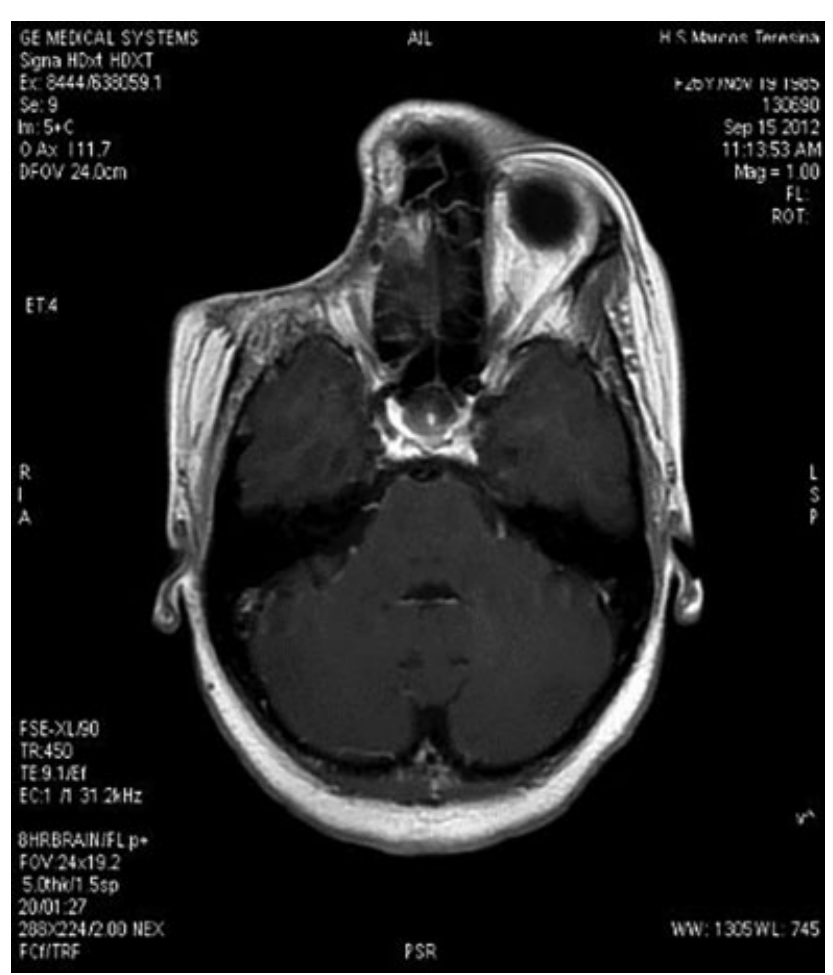

Fig. 6 Postsurgical control image.

subependimoma and the myopopapillary ependymoma; in grade II the ependymoma; and grade III anaplastic ependymoma. ${ }^{11-14}$

In general, some histological structures are characteristic of ependymomas, and are important for their identification, such as perivascular rosettes, which consist of a perivascular anuclear zone of ependymal cells distributed radially close to the blood vessels. Another peculiar structure is the ependymal rosettes, which, although very characteristic of ependymomas, are extremely rare, consisting of tumor cells distributed concentrically around the lumen, forming a canal. ${ }^{11,13}$

Clear-cell ependymomas are generally grade II tumors, predominantly supratentorial, affecting more adolescents and young adults, as in the case reported in the present article. As a histological parameter, they have oval cells with dense chromatin, surrounded by light halos, similar to oligodendroglioma, but differing from it because the latter has no intraventricular location. Central neurocytoma is a differential diagnosis, and it should be confirmed by an immunohistochemical exam if there is doubt concerning the diagnosis. When proliferation and mitoses of endothelial cells are found, they are considered grade III tumors, as was the case of the patient described in the present article. ${ }^{11,13}$

The clinical manifestations triggered by ependymomas are variable, depending on the size of the tumor and its location. Those located in the posterior fossa are often related to obstruction of the IV ventricle and obstructive hydrocephalus. Because it is located near the vomit center, the presence of nausea and emesis followed by headache is common. Moreover, due to the compression effect on the posterior fossa structures, ependymomas can occur with ataxia, hemiparesis, vertigo, visual disturbance and neck pain. In supratentorial ependymomas, it is common to see an increase in intracranial pressure, which manifests as headache, nausea, vomiting, cognitive impairment, and lowering of the consciousness level, as was the case of the patient in question. When located in the spinal cord, the first symptom is dysesthesia, due to the neoplasm that originates in the central canal of the spinal cord, which is similar to what occurs in syringomyelia. ${ }^{3,13}$

For the diagnosis of ependymomas, as well as of other clinical situations of suspicion of mass effect, computed tomography $(\mathrm{CT})$ and the MRI are essential. ${ }^{6,15,16}$ The CT is effective in the diagnosis of infratentorial ependymomas, usually presenting isointense to the brain parenchyma and with calcifications. In the MRI, the tumor image is hypointense in T1 and hyperintense in $\mathrm{T} 2$ in relation to the encephalic parenchyma. In both T1 and $\mathrm{T} 2$, the tumor is heterogeneous. Spinal-cord MRI is still used in cases of suspicion of cauda equina and terminal filament tumors. Because of the neuroepithelial tumors that affect mostly the spinal cord and in $11 \%$ of the cases they are classified as CSF, it is necessary to perform a spinal-cord MRI and an analysis of the CSF by lumbar puncture (without contraindications) in every case. , $^{3,16}$

The treatment consists of total surgical resection, which is not always possible due to the infiltrative character of the tumor, which can occur in noble areas of the brain. The MRI should be performed in the immediate postoperative period (the first 48 hours) to evaluate the residual disease, while hemoglobin degradation artifacts and local inflammatory reactions in the surgical site are not yet present. The surgical treatment can be complemented by radiotherapy, which should be applied to the spinal cord in a smaller dose if there is confirmation of tumor cells in the CSF or confirmation of the tumor by a spinal-cord MRI. In spite of this, there are no studies with a high degree of clinico-epidemiological evidence that justifies the use of adjuvant radiotherapy, which is contraindicated for children under 3 years of age and in cases in which there was total resection of the tumor, since the risk of side effects in the long term outweighs the benefits of the procedure. For recurrent ependymomas, if the patient has not yet undergone radiotherapy, it should be the recommended therapy; however, if the therapy has already been performed, then chemotherapy, radiation therapy or palliative care should be adopted. ${ }^{10}$ The role of chemotherapy has not yet been well established, but it should only be performed in cases of tumor recurrence, as in the case reported in the present article. $3,6,7,14,15,17$

Recurrent intracranial ependymomas occur in almost $50 \%$ of the cases, but the extracerebral recurrence of ependymomas is extremely rare. ${ }^{8-10}$ It is known that intracranial gliomas may occasionally develop extraneural metastases. ${ }^{18}$ However, this event is determined in virtually all instances by prior operative decompression, and a similar thing occurred in the case reported in the present article (Russell and Rubinstein, 1963, p. 219; ${ }^{19}$ Smith et al, 1969). ${ }^{24}$ Examples of this extracerebral complication in ependymomas remain very uncommon, and when they occur, the cervix, the thorax and the lumbar spine are more common sites. ${ }^{20,21}$ Some cases of extracerebral metastasis of ependymomas have been reported in the literature. Regarding the cases of euthymic 
metastasis of cauda equine tumors verified at necropsy, we highlight the ones reported by Weiss, $1955 ;{ }^{27}$ Sharma, $1965 ; 22$ Patterson et al, $1961 ;{ }^{10}$ and Rubinstein and Logan, $1970 .^{20}$ Other cases of extraneural metastases of ependymomas have been reported, such as the propagation into the internal auditory canal by a spinal myxopapillary ependymoma, described by Kittel et al, 2001; ${ }^{17}$ a case of metastasis to the lungs and regional lymph nodes, described by MacMahon and Urista in $1964^{13}$, at a time when only 5 cases of extraneural ependymoma metastasis had been reported. In 1984 , Andoh et $\mathrm{al}^{26}$ also described a case of multiple pulmonary, pleural and lymph node metastases, which were supraclavicular and paraortic. A case similar to the one reported in the present article was described by Rutka et $\mathrm{al}^{21}$ in 1985: the extracerebral extension of a cystic ependymoma, due to the fact that the third ventricle, in the pre-chiasmatic cistern, compressed the right optic nerve, causing progressive monocular visual loss. Still according to Rutka et al, ${ }^{21}$ the extracerebral growth of primary intracerebral gliomas can cause optic neuropathy, and it is indistinguishable from other compressive neuropathies. Intraorbital recurrence, as presented in the case reported in the present article, is a very rare event, with only a few cases reported in the literature. It is presumed that, in most cases, the route of distant dissemination of ependymomas is the hematogenic route. ${ }^{29}$ This idea is reinforced because of very exceptional cases in which the extraneural deposits developed in the absence of a previous craniectomy (Rubinstein, 1967). ${ }^{18}$ As for the metastatic route of propagation, the venous route has a greater permeability, playing an important role in the origin of extracerebral glioma metastases, which has already been demonstrated in previous studies. ${ }^{30}$

\section{Conclusion}

The case described in the present article is uncommon due to the intraorbital extracerebral recurrence of the anaplastic ependymoma. As for the procedure performed, the expected success was obtained. Because of the periorbital soft tissue and orbital bone involvement by the neoplasia, the therapeutic option for tumor resection with orbital exenteration was successful.

\section{Conflicts of Interest}

The authors have none to disclose.

\section{References}

1 ALBERTA HEALTH SERVICES. Ependymoma. Clinical practice guideline CNS-004, version 2. 2009. Revised May, 2012.

2 Villano JL, Parker CK, Dolecek TA. Descriptive epidemiology of ependymal tumours in the United States. Br J Cancer 2013;108 (11):2367-2371

3 Chaves MLF, Finkelsztejn A, Stefani MA, et al. Rotinas em Neurologia e Neurocirurgia. Porto Alegre: Artmed; 2009

4 Bergsagel DJ, Finegold MJ, Butel JS, Kupsky WJ, Garcea RL. DNA sequences similar to those of simian virus 40 in ependymomas and choroid plexus tumors of childhood. N Engl J Med 1992;326 (15):988-993

5 Lednicky JA, Garcea RL, Bergsagel DJ, Butel JS. Natural simian virus 40 strains are present in human choroid plexus and ependymoma tumors. Virology 1995;212(02):710-717
6 Aminoff MJ. Neurology and General Medicine. 4th ed. Churchill Livingstone Elsevier; 2008

7 Glasauer FE, Yuan RHP. Intracranial Tumors with Extracranial Metastases: Case report and review of the literature. J Neurosurg 1963;20:474-493

8 Antony R, Wong KE, Patel M, et al. A retrospective analysis of recurrent intracranial ependymoma. Pediatr Blood Cancer 2014; 61(07):1195-1201

9 Miyazawa T, Hirose T, Nakanishi K, Uozumi Y, Tsuzuki N, Shima K. Supratentorial ectopic cortical ependymoma occurring with intratumoral hemorrhage. Brain Tumor Pathol 2007;24(01):35-40

10 Patterson RH Jr, Campbell WG Jr, Parsons H. Ependymoma of the cauda equina with multiple visceral metastases. Report of a case. J Neurosurg 1961;18:145-150

11 Friede RL, Pollak A. The cytogenetic basis for classifying ependymomas. J Neuropathol Exp Neurol 1978;37(02):103-118

12 Godfraind C. Classification and controversies in pathology of ependymomas. Childs Nerv Syst 2009;25(10):1185-1193

13 MacMahon HE, Urista MS. The spread of an ependymoma from the brain to the lungs: Case report. Am J Surg 1964;107(05): 765-768

14 Acquaye AA, Vera E, Gilbert MR, Armstrong TS. Clinical presentation and outcomes for adult ependymoma patients. Cancer 2017; 123(03):494-501

15 Massimino M. Ependymoma. Orphanet Encyclopedia, 2004https:// www.orpha.net/data/patho/GB/uk-ependymoma.pdf

16 Louis DN, Ohgaki H, Wiestler OD, et al. The 2007 WHO classification of tumours of the central nervous system. Acta Neuropathol 2007;114(02):97-109

17 Kittel K, Gjuric M, Niedobitek G. [Metastasis of a spinal myxopapillary ependymoma to the inner auditory canal]. HNO 2001;49 (04):298-302

18 Rubinstein LJ. Development of extracranial metastases from a malignant astrocytoma in the absence of previous craniotomy. Case report. J Neurosurg 1967;26(05):542-547

19 Russell DS, Rubinstein LJ. Pathology of Tumours of the Nervous System. 2nd ed. Edward ArnoldLondon1963

20 Rubinstein LJ, Logan WJ. Extraneural metastases in ependymoma of the cauda equina. J Neurol Neurosurg Psychiatry 1970;33(06): 763-770

21 Rutka JD, Sharpe JA, Resch L, Fleming JF. Compressive optic neuropathy and ependymoma of the third ventricle. J Clin Neuroophthalmol 1985;5(03):194-198

22 Sharma KD. A metastasizing ependymoma of the cauda equina. Indian J Med Sci 1965;10:639-641

23 Shuangshoti S, Rushing EJ, Mena H, Olsen C, Sandberg GD. Supratentorial extraventricular ependymal neoplasms: a clinicopathologic study of 32 patients. Cancer 2005;103(12): 2598-2605

24 Smith DR, Hardman JM, Earle KM. Metastasizing neuroectodermal tumors of the central nervous system. J Neurosurg 1969;31 (01):50-58

25 Suren EG. [Metastasizing extracerebral ependymoma]. Nervenarzt 1974;45(10):552-556

26 Andoh T, Kagawa Y, Sakai N, et al. [Extracranial metastasis of ependymoma. Case report]. Neurol Med Chir (Tokyo) 1984;24 (10):800-807

27 Weiss L. A metastasizing ependymoma of the cauda equina. Cancer 1955;8(01):161-171

28 Yilmaz N, Kiymaz N, Mumcu C, Bayram I. Extra-axial subarachnoid ependymoma mimicking a PCA Schwannoma. Turk Neurosurg 2005;15(03):162-165

29 Yuh EL, Barkovich AJ, Gupta N. Imaging of ependymomas: MRI and CT. Childs Nerv Syst 2009;25(10):1203-1213

30 Yurt A, Selçuki M, Ertürk AR, Küpelioglu A. Large supratentorial cortical ependymoma in a child. Clin Med Res 2010;8(01):25-27

31 Bailey P, Cushing HA. Classification of the Tumours of the Glioma Group on a Histogenetic Basis, with a Correlated Study of 
Prognosis. Philadelphia, PA; London; Montreal, QC: J. B. Lippincott Company; 1926

32 Kernohan JW, Ody FA. Classification histologique des gliomes de la moelle épiciére et du filum terminale. Schweiz Arch Neurol Psychiatry 1932;29:113
33 Scheinker IM. Subependymoma: a newly recognized tumor of subependymal derivation. J Neurosurg 1945;2:232-240

34 Kawano N, Yada K, Yagishita S. Clear cell ependymoma. A histological variant with diagnostic implications. Virchows Arch A Pathol Anat Histopathol 1989;415(05):467-72 